\title{
A HERMENÊUTICA DE PROFUNDIDADE E O DESIGN GRÁFICO PARA A PERSUASÃO
}

\author{
Cavalcante, A. L. B. L; Braglia, I. de A.; Barros, V. T. de O; Fialho, F. A. P.; Remor, C. A. M.
}

RESUMO

0 poder da mídia em uma sociedade tem sido estudado e discutido em várias áreas do saber. A interpretação dos produtos de Design Gráfico pelos usuários pode ser uma questão em que a hermenêutica e a psicanálise podem contribuir já que a primeira é a ciência da interpretação e a segunda refere-se à ciência que estuda o comportamento e processos mentais. Este artigo apresenta a metodologia Hermenêutica de Profundidade e sua utilização na interpretação do design de peças gráficas de persuasão. Realizou-se um levantamento de dados, em referências bibliográficas, de algumas formas simbólicas e propagandas de guerra, demonstrando o Design Gráfico a serviço do controle e da influência. A utilização de imagens de figuras humanas, por vezes, personalidades conhecidas pelo público foco de determinada campanha tem a função de convencer, impor uma ação ou por muitas vezes quebrar paradigmas ao mudar um pensamento.

Palavras chave: design gráfico, persuasão, Hermenêutica de Profundidade.

\section{ABSTRACT}

The power of the media in a society has been studied and discussed in various areas of knowledge. The interpretation of graphic design products for users can be an issue on which hermeneutics and psychoanalysis can contribute as the first is the science of interpretation and the second refers to the science that studies behavior and mental processes. This article presents the methodology Depth Hermeneutics and its use in interpreting the design of graphic elements of persuasion. We conducted a survey of data, bibliographic references, in some ways symbolic of war and propaganda, showing graphic design in the service of control and influence. The use of images of human figures, sometimes personalities known to the public focus of the campaign has given the task of convincing to impose a deed or paradigms often break when changing a thought.

Key-words: Graphic Design, persuasion, Hermeneutics.

\section{INTRODUÇÃO}

As mídias produzidas pelo Design Gráfico, impressas ou digitais, são desenvolvidas de acordo com um determinado projeto. Muitas vezes com foco na publicidade, um produto ou serviço de Design Gráfico pode possuir um caráter alienante para o seu público, por pressupor, conforme Ferreira (2009, p. 134), uma redução da possibilidade de contato direto entre as pessoas.

No design, a comunicação popular é tema de estudo. Na etapa de conceituação em um projeto de Design Gráfico tem-se o momento em que ocorrerá a verbalização para a síntese do conceito do produto a 
ser passado a um determinado usuário. Esta síntese será a base conceitual do produto final, sua concisão gráfica.

Aborda-se, neste artigo, as funções do Design Gráfico em que uma delas é a persuasão, também o entendimento sobre transmissão cultural, e ainda, a hermenêutica como método de compreensão da imagem. Ao final, expõem-se exemplos históricos do Design Gráfico de campanhas políticas em momentos de conflitos militares.

\section{AS FUNÇÕES DO DESIGN GRÁFICO}

Hollis (2001) afirma que a principal função do Design Gráfico é identificar: dizer o que é determinada coisa, ou de onde ela veio. Sua segunda função, conhecida no âmbito profissional como Design de Informação, é informar e instruir indicando a relação de uma coisa com outra quanto à direção, posição e escala. Por fim, Hollis (2001) apresenta a terceira função, muito diferente das outras duas, é apresentar e promover; e aqui o autor diz que o objetivo do design é prender a atenção e tornar sua mensagem inesquecível.

Inserido nesse contexto, o autor mostra que o Design Gráfico faz parte, atualmente, da cultura e da economia dos países industrializados. No entanto, Barnard (2005) cita que as mensagens e imagens podem, atualmente, serem transmitidas em um instante pelo mundo todo, já Hollis (2001) diz que os avanços continuam sendo surpreendentemente localizados e, ainda, que a maioria dos designers trabalhem em equipe, as mudanças ainda estão associadas a pioneiros isolados. Todavia, o autor expõe a idéia de que novas formas são desenvolvidas em respostas às pressões comerciais e mudanças tecnológicas, ao mesmo tempo em que o Design Gráfico continua a se alimentar de suas próprias direções. Deste modo, Hollis (2001) conclui que o Design Gráfico constitui uma espécie de linguagem, de gramática imprecisa e vocabulário em contínua expansão.

Quanto às funções do Design Gráfico, Malcom Barnard (2005) diz que as mesmas podem ser abordadas a partir de duas direções: as funções sociais, culturais e econômicas do projeto gráfico e as funções de exemplo individual do Design Gráfico. A primeira é de "identificação": o objetivo do Design Gráfico é dizer o que algo é, ou de onde veio (HOLLIS, 1994 apud BARNARD, 2005). Segundo Hollis a função de "informação e instrução" e o trabalho do Design Gráfico é "indicar a relação de algo em outra direção, posição e escala". Mapas, diagramas e sinais de sentido são propostos como exemplos de gráficos que exercem essas funções. E a terceira função é a de apresentação e promoção (HOLLIS, 1994 apud BARNARD, 2005).

Jaques Amount (1997) sugere a existência de três antigas funções de desempenho gráfico. Barnard diz que Amount explica essas funções como "simbólica", "epistêmica" e "estética". Verifica-se que nenhuma dessas definições da função do Design Gráfico nos é satisfatória: ambas são incompletas e, para Amount, 
Hollis (2001) está beirando a tautologia1. Desse modo, Malcolm Barnard (2005) contesta essas definições. Ele mostra que há pouco espaço para a função retórica, por exemplo, nessas definições. Hollis (2001) menciona a palavra "promoção", mas explica cartazes e anúncios somente em termos de serem "atraentes" e memoráveis: não há nenhuma menção de persuasão ou de alteração do comportamento da pessoa, no máximo que os anúncios estimulam os cidadãos a participar do esforço de guerra, por exemplo (Hollis, 2001, p.28). Amount (1997) também não encontra lugar para imagens de retórica: ele menciona a publicidade, mas a explica em termos artísticos e estéticos.

Desse jeito, Barnard (2005) apresenta as funções do Design Gráfico diferente das visões de Richard Hollis (2001) e Jaques Amount (1997). Mesmo assim, ele permeia as idéias por eles expostas, visando contribuir e unificar o pensamento para a produção gráfica. Sendo assim, Barnard (2005) classifica as funções do Design Gráfico da seguinte maneira:

\section{Função de informação}

A primeira função é a informação. 0 papel do Design Gráfico está aqui para conferir (por novas definições) de conhecimento, ou inteligência. Claramente, esta é praticamente a mesma função epistêmica de Amount (1997) e cobre tudo o que foi descrito por Hollis (2001). Sinais publicitários, fachadas, brasões, logotipos de empresa e de embalagem são todos exemplos de Design Gráfico em que um dos papéis desempenhados é o de fornecer informações. As informações fornecidas podem ser muito básicas, e podem estar em um estabelecimento comercial e não em uma residência, por exemplo.

\section{Função de Persuasão}

A segunda função é a persuasão, retórica ou simplesmente função. Aqui o trabalho do Design Gráfico é persuadir, convencer ou apenas afetar uma mudança no pensamento ou comportamento. Novamente, isto se assemelha a Amount (1997) com a descrição da imagem retórica. Pode-se argumentar que toda a produção gráfica tem uma função retórica, que tudo existe para mudar o pensamento das pessoas ou o comportamento de uma forma ou de outra. A função retórica assume muitas formas. A publicidade é apenas um exemplo mais visível e pode ser localizado em um espectro de produção gráfica que vai desde propaganda política e publicidade eleitoral até ilustração ou documentários.

\section{Função de Decoração}

A terceira função é a função decorativa ou estética. É a idéia de que o projeto gráfico pode ter uma função decorativa, que pode ser divertida, ou que poderia ser divertida, ornamental e fonte de alegria e prazer. Amount (1997) começa a se aproximar dessa função quando ele descreve imagens estéticas como sendo destinadas a agradar ao espectador, mas como Hollis (2001), sua descrição não chega a se explicar como produção gráfica decorativa.

\footnotetext{
1 “(gr. tautologia) 1. Proposição na qual o predicado simplesmente repete aquilo que já está contido no sujeito". (Japiassú \& Marcondes, 2001, p.257).
} 


\section{Função Mágica}

Para Barnard (2005) a quarta função é a função mágica. Esta é provavelmente a função menos óbvia da produção gráfica. No entanto, ela tenta analisar e explicar duas coisas que o Design Gráfico faz. A primeira é sugerida por Amount (1997) quando ele faz a sugestão de que as imagens simbólicas possuem alguma forma de subvenção e "acesso à esfera do sagrado". A segunda é aludida por Kalman (1991), quando ele diz que o Design Gráfico é mais sobre "fazer algo diferente do que ele realmente é", o autor ainda diz que as imagens transformam uma coisa em outra coisa. Ignorando por ora essa questão de saber se pode ter acesso ao "o que realmente é", fazer coisas aparecer e transformar uma coisa em outra coisa é exatamente o que os mágicos fazem. Assim também é o Design Gráfico para Barnard (2005) que, por meio desse pensamento, pode-se dizer que o design possui uma função mágica, mesmo que nos pareça um tanto quanto residual ou primitiva.

De qualquer forma, essas definições das funções do Design Gráfico apresentadas por Barnard (2005) são mais pertinentes à linha de pensamento sobre o Design Gráfico sugeridas por Jorge Frascara (2004) que, em resumo, afirma que o Design Gráfico se ocupa com a construção de mensagens visuais com o propósito de afetar o conhecimento, as atitudes e o comportamento das pessoas. Uma comunicação chega a existir porque alguém quer transformar uma realidade existente em uma realidade desejada. Para Frascara (2004), o designer é o responsável pelo desenvolvimento de uma estratégia comunicacional, pela criação de elementos visuais para implantar e contribuir com a identificação e a criação de outras ações de apoio destinadas a alcançar os objetivos propostos. É proporcionar a criação dessa realidade desejada. Assim, para o autor torna-se indispensável um estudo cuidadoso do público, em particular quando se tenta gerar trocas em suas atitudes e comportamentos. A avaliação da efetividade da campanha deve formar parte do processo de design, para ajustar os componentes e melhorar os efeitos da campanha comunicacional.

\section{A HERMENÊUTICA E A IMAGEM COMO TEXTO VISUAL NO DESIGN GRÁFICO}

Considera-se aqui a imagem como texto visual. Neste sentido, a arte de compreensão de textos se fundamenta na teoria de Habermas (2003, p. 40,41), segundo a qual a epistemologia se ocupa da relação entre a linguagem e a realidade, ao passo que a hermenêutica tem de se ocupar, ao mesmo tempo, da tríplice relação de um proferimento que serve:

(a) como expressão da intenção de um falante;

(b) como expressão para o estabelecimento de uma relação interpessoal entre falante e

ouvinte;

(c) como expressão sobre algo no mundo.

Trata-se aqui do "falante" um emissor (o projetista, o designer) e o "ouvinte" o receptor (o usuário da mensagem ou consumidor do produto).

A imagem no Design Gráfico é vista como um discurso visual. 0 discurso, em filosofia, é um 
modo de pensamento que se opõe a intuição. "Pensamento discursivo" - é um pensamento operando em um raciocínio, em um percurso para atingir seus objetivos por meio de etapas intermediárias.

A filosofia contemporânea, especialmente a filosofia da linguagem, a hermenêutica e o existencialismo, valorizam a análise do discurso como método próprio à filosofia, considerando o discurso não apenas como o simples texto, mas como o próprio campo de constituição do significado em que se estabelece a rede de relações semânticas com a visão de mundo que pressupõe (JAPIASSÚ \& MARCONDES, 1991, p.56).

A hermenêutica, do grego hermeneutikós, de hermeneuein, significa interpretar. 0 termo é originalmente teológico e designa a metodologia própria à interpretação da Bíblia. Depois passou a designar "todo esforço de interpretação científica de um texto difícil que exige uma explicação". No século XIX, Dilthey ${ }^{2}$ vinculou o termo "hermenêutica a sua filosofia da "compreensão vital": as formas da cultura, no curso da história, devem ser apreendidas por meio da experiência íntima de um sujeito; cada produção espiritual é somente o reflexo de uma cosmovisão. Atualmente, a hermenêutica constitui uma reflexão filosófica interpretativa ou compreensiva sobre os símbolos e os mitos em geral" (JAPIASSÚ \& MARCONDES, 1991, p.126).

Paul Ricoeur ${ }^{3}$ cita duas hermenêuticas:

a) a que parte de uma tentativa de transcrição filosófica do freudismo, concebido como um texto resultante da colaboração entre o psicanalista e o psicanalisado;

b) a que culmina numa "teoria do conhecimento", oscilando entre a leitura psicanalítica e uma fenomenologia. (JAPIASSÚ \& MARCONDES, 1991, p.92).

É nesta última que o presente trabalho se apóia e que será explanado posteriormente e realizada uma menção à transmissão de informações para uma coletividade.

\section{ASPECTOS DA TRANSMISSÃO CULTURAL E COMUNICAÇÃO DE MASSA}

Conforme Thompson (1995, p.221), a transmissão cultural é uma troca de formas simbólicas (fenômenos sociais) entre produtores e receptores. Esta transmissão cultural é distinguida pelos seguintes aspectos: meio técnico de transmissão; aparato institucional de transmissão e distanciamento espaçotemporal implicado na transmissão. 0 meio técnico é o substrato material de uma forma simbólica. Como a

\footnotetext{
2 (1833-1911) 0 filósofo alemão Wilhelm Dilthey engajou-se numa via de pensamento (aberta por

Schopenhauer e Nietzche) valorizando a chamada "teoria da visão do mundo" (Weltanschauung), em que "viver é apreciar", avaliar, escolher, dar sua "interpretação" ao mundo natural: cada sistema filosófico tem por verdade a psicologia de seu autor, sua "visão do mundo", exprimindo-se numa "maneira de ver" que é "um modo de ser". Sua obra fundamental é a Introdução ao estudo das ciências humanas (1883), na qual critica a concepção positivista da explicação (causal e racionalista) e procura compreender a realidade humana, essencialmente social e histórica. (JAPIASSÚ \& MARCONDES, 1991, p.72).

${ }^{3}$ Filósofo francês preocupado em atingir e formular uma teoria da interpretação do ser, toma como seu problema próprio o da hermenêutica, vale dizer, o da extração e da interpretação do sentido. Convencido de que todo o pensamento moderno tornou-se interpretação, elabora uma grande simbólica da consciência, que se encontra na mesma raiz de todas as determinações históricas e espirituais do homem. Ao revisar a problemática hermenêutica, passa a entendê-la como a teoria das operações de compreensão em sua relação com a interpretação dos textos. Para ele, é o símbolo que exprime nossa experiência fundamental e nossa situação no ser (JAPIASSÚ \& MARCONDES, 1991, p.236).
} 
mesma é produzida e transmitida. Alguns atributos são citados por Thompson (1995, p.221-225), a saber: a fixação; a reprodução e a participação dos indivíduos que empregam determinado meio. Os meios técnicos estão ligados as diferentes habilidades, faculdades e recursos. Não é possível dissociar totalmente um meio técnico de um contexto social em que é empregado pelos envolvidos na codificação e decodificação de formas simbólicas (THOMPSON, 1995, p.223).

0 aparato institucional de transmissão é um conjunto de articulações institucionais em que o meio técnico é elaborado e os indivíduos envolvidos estão inseridos. São hierarquias e graus de controle sobre o processo de transmissão cultural. (THOMPSON, 1995, p.225). Um pôster, por exemplo, é um suporte técnico e sua reprodução e publicação depende das instituições envolvidas em todo o processo, assim como sua regulação e controle. Sobre o aspecto de distanciamento espaço-temporal, o autor se apóia em Harold Innis e Anthony Giddens que enfatizaram a importância do espaço e do tempo para a teoria social e para a análise dos sistemas de comunicação. A transmissão de uma forma simbólica implica no desligamento dessa forma do contexto de sua produção, podendo ser localizada em diferentes tempos e locais. Thompsom (1995, p.225) distingue dois atributos deste distanciamento. Um é o "contexto de co-presença", como uma conversação limitada aos seus participantes sem aparatos técnicos de transmissão. E outro atributo é "extensão de acessibilidade" em que sua extensão depende do meio técnico de transmissão e do aparato técnico institucional.

O papel, por exemplo, é um material utilizado desde épocas remotas em suportes técnicos leves e transportáveis. A evolução continuada das redes de comunicação baseadas em computador amplia a acessibilidade no espaço e tempo, possibilitando flexibilidade e maior controle pelos usuários.

A comunicação de massa é concebida pela "produção institucionalizada e a difusão generalizada de bens simbólicos através da transmissão e do armazenamento da informação" (THOMPSON, 1995, p.288). A mesma possui quatro características: a produção e difusão institucionalizadas de bens simbólicos; a ruptura instituída entre produção e recepção; a extensão da disponibilidade no tempo e no espaço; e a circulação pública das formas simbólicas.

As formas simbólicas utilizadas para persuasão são provenientes de uma produção institucionalizada no intuito de mobilizar um público específico para uma determinada ação. Estas carregam símbolos pertencentes a este público, tornando as mensagens próximas ao mesmo. Podem ser retóricas ou diretas, mas tocam a fundo a consciência do receptor incentivando-o à ação.

\section{HERMENÊUTICA - A METODOLOGIA DA INTERPRETAÇÃO}

Após desenvolver uma visão teórica sobre cultura, ideologia e comunicação de massa, Thompson (1995, p.355) argumenta que a análise das formas simbólicas pode ser conceitualizada em termos de um marco referencial metodológico descrito como "hermenêutica de profundidade". Neste referencial, segundo o autor, o objeto de análise é uma construção simbólica, que exige uma interpretação. As formas simbólicas 
estão inseridas em diferentes contextos sociais e históricos, por esta razão é necessário o emprego de outros métodos de análise que podem ser inter-relacionados.

Da Grécia clássica aos séculos XIX e XX, a hermenêutica se transforma e, principalmente, a partir dos filósofos hermeneutas, tais como Dilthey, Heidegger, Gadamer e Ricoeur. Estes pensadores ressaltam que o estudo das formas simbólicas é fundamentalmente um problema de compreensão e interpretação (THOMPSON, 1995, p.357).

A hermenêutica recorda que os sujeitos são capazes de compreender, refletir e agir fundamentados nessa compreensão e reflexão e que também que "os sujeitos que constituem parte do mundo social estão sempre inseridos em tradições históricas" (THOMPSON, 1995, p.360).

Ricoeur construiu, a partir de Heidegger e Gadamer, a explicitação que a hermenêutica pode oferecer uma reflexão filosófica do ser e a compreensão como uma reflexão metodológica sobre a natureza e tarefas da interpretação na pesquisa social (THOMPSON, 1995, p.362). A esta reflexão é o que Ricoeur e outros intitularam de Hermenêutica de Profundidade (HP) que tem por idéia que o processo de interpretação pode ser mediado por diversos métodos explanatórios, podendo ser empregado na análise da ideologia. Esta análise pode ser vista como uma forma de HP. Como nas inter-relações entre significado e poder, nas maneiras que as formas simbólicas podem ser usadas para dominar, a análise da ideologia levanta novas questões concernentes aos usos das formas simbólicas, como é possível verificar no histórico, uso e apropriações dos símbolos da suástica e da paz (Figuras 7 e 8).

De acordo com o Referencial Metodológico da Hermenêutica de Profundidade descrito por Thompson (1995, p.365), na figura 1 apresentam-se as três fases de enfoque da Hermenêutica de Profundidade.

Análise sócio-histórica $\left\{\begin{array}{l}\text { Situações espaço-temporais } \\ \text { Campos de interação } \\ \text { Instituições sociais } \\ \text { Estrutura social } \\ \text { meios técnicos de transmissão }\end{array}\right.$
Análise formal
ou Discursiva $\left\{\begin{array}{l}\text { Análise semiótica } \\ \text { Análise da conversação } \\ \text { Análise sintática } \\ \text { Análise narrativa } \\ \text { Análise argumentativa }\end{array}\right.$

Interpretação/Re-interpretação

Figura 1 - Referencial Metodológico da Hermenêutica de Profundidade, retirado da figura Formas de Investigação Hermenêutica. Fonte: Thompson (1995, p.365, Fig. 6.1). 
Dentro de cada uma dessas fases vários métodos de pesquisa podem estar à disposição e tais métodos podem se apresentar mais adequados. Tudo dependerá do objeto de análise e das circunstâncias da investigação.

Na primeira fase, a "análise sócio-histórica", compreende-se que as formas simbólicas são produzidas, transmitidas e recebidas em condições sociais específicas e o objetivo desta fase é reconstruir as condições sociais e históricas de produção, circulação e recepção destas formas simbólicas. Nesta fase, o primeiro aspectos a ser pontuado é "espaço-temporal" que trata da reconstrução de ambientes específicos em que as pessoas agem e reagem a tempos particulares e locais especiais. As formas simbólicas situam-se dentro de "campos de interação" em que são analisadas as relações entre as pessoas. Já as "instituições sociais" são vistas como conjuntos de regras e recursos. É uma análise da estrutura social, pois procura identificar as assimetrias, as diferenças e as divisões. É uma análise que demanda uma reflexão mais teórica e exige uma proposição de critérios, formulação de categorias e distinções que auxiliem na organização das evidências das assimetrias da vida social (THOMPSON, 1995, p.367). Para finalizar esta fase sócio-histórica, tem-se para o estudo das formas simbólicas os "meios técnicos de construção de mensagens e transmissão" como já mencionado no presente artigo (p.5)

São esses que conferem determinadas características às formas simbólicas e certos graus de fixidez, reprodutibilidade, e possibilidades de participação para os sujeitos que empregam o meio.

A produção de objetos e expressões significativas é possível por causa da existência de regras e recursos disponíveis ao produtor. É uma produção orientada à circulação e recepção de formas simbólicas dentro do campo social.

Esta fase sócio-histórica, portanto, define as condições e contextos sócio-históricos de produção, circulação e recepção das formas simbólicas e examina as convenções, as instituições e as relações de poder.

A segunda fase da análise da Hermenêutica de Profundidade é a "análise formal ou discursiva". Nesta, as formas simbólicas são percebidas como ações situadas, baseadas em regras, recursos e construções complexas em que algo é expresso. São produtos contextualizados que visam dizer algo sobre alguma coisa. É a fase da interpretação e re-interpretação. Propõe-se que não seja discutido isoladamente da análise sócio-histórica.

Várias maneiras podem se conduzir a análise formal. Uma delas é a “Análise Semiótica” que é, segundo Thompson (1995, p. 370), vista como:

o estudo das relações entre os elementos que compõe a forma simbólica, ou o signo, e das relações entre seus elementos e os do sistema mais amplo, do qual a forma simbólica, ou o signo, podem ser parte.

Em campanhas de guerra, por exemplo, as imagens eram produzidas associando-as às 
pessoas com autoridade ou aos anseios daquele determinado público.

Complementam esta análise formal as análises da conversação, sintática, narrativa e argumentativa.

A última fase do enfoque da hermenêutica de profundidade é a interpretação/reinterpretação, que constrói sobre a análise formal e sócio-histórica e se apresenta complexa, conflituosa e aberta à discussão. As formas simbólicas possuem significados por vezes obscuros e difíceis de interpretação. Propor uma análise de tais formas em suportes técnicos produzidos por demandas políticas é o que se apresenta no próximo tópico.

\section{DESIGN PARA PERSUASÃO E SEUS CONTEXTOS SÓCIO-HISTÓRICOS}

Conforme Hollis (2000, p. 28), a Primeira Guerra Mundial estabeleceu a importância do Design Gráfico. Foram diagramas, ilustrações e pôsteres que auxiliavam nas informações que os governos queriam repassar à população. Em todos os países, os pôsteres apelavam para o patriotismo e ao sentimento de culpa, por saber que outros arriscavam a vida por ele (HOLLIS, 200, p.29).

A figura 2 demonstra uma ilustração bastante significativa junto à questão: "Pai, o que você fez durante a Grande Guerra?". Esta sugere com o estilo da sala e a indumentária das crianças a prosperidade do período pós-guerra e a imagem do menino brincando com soldados de brinquedo demonstrando o "correto espírito masculino, imbuído de militarismo romântico" (HOLLIS, 2000, p.29).

Na Grã-Bretanha utilizaram também a imagem sem retórica, direta e factual. A figura 3 traz o relevante pôster com a figura de Lord Kitchener, o ministro da guerra, personalidade facilmente reconhecida pela população da época que ao apontar para frente, persuadia diretamente o público específico. Isto foi utilizado pelo motivo que, naquele momento, não era obrigatório o serviço militar. Este design inspirou o pôster americano de Flagg (figura 4), representando o “Tio Sam4”. Já na Alemanha, conforme Hollis (200, p.30), como o serviço militar era obrigatório, não eram necessárias campanhas de recrutamento, entretanto, a Guerra consumia grande quantidade de munição e suprimentos, fazendo com que o Estado utilizasse os pôsteres para persuadir os cidadãos a emprestar-lhe dinheiro, por meio de subscrições para empréstimos de Guerra.
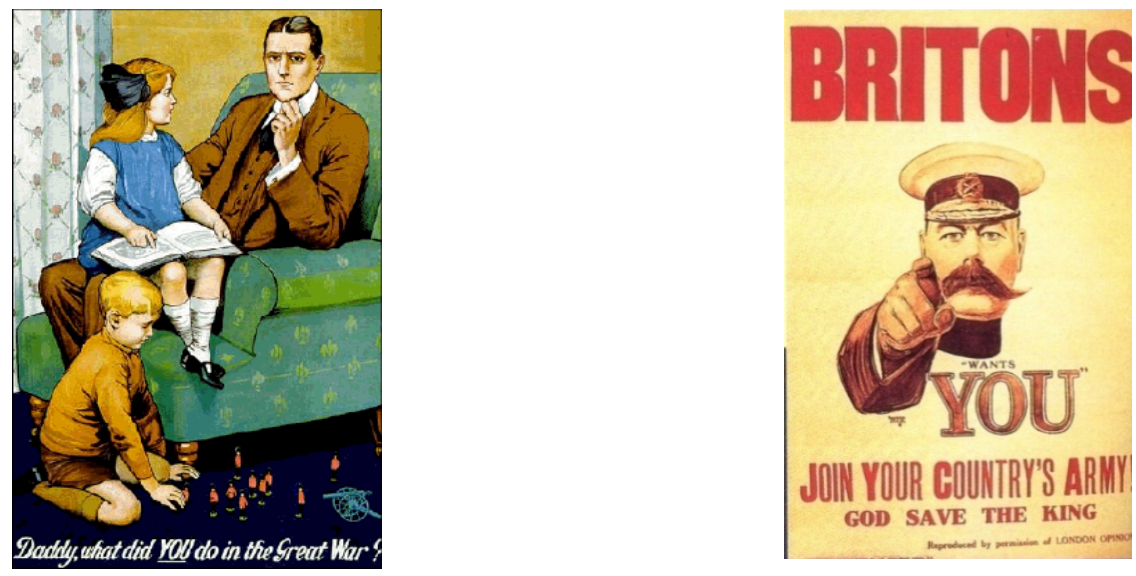

${ }^{4}$ Personificação nacional do governo americano, originalmente usado na guerra de 1812. 
Figura 2 - Pôster: "Pai, o que você fez durante a Grande Guerra?", 1915, Savile Lumley. Fonte: HOLLIS, 2000, p. 29.

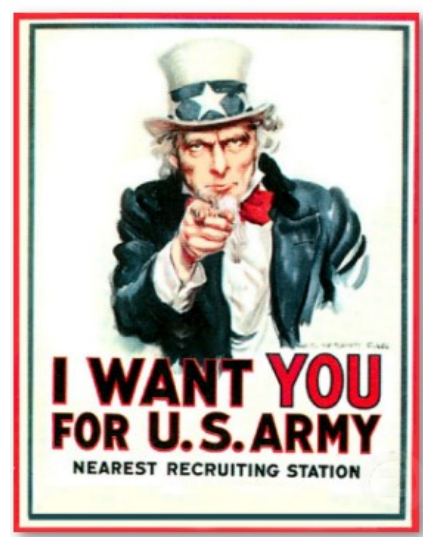

Figura 4 - Pôster: "Quero você no Exército dos Estados Unidos", 1917, James Montgomery Flagg. Fonte: HOLLIS, 2000, p.29.
Figura 3 - Pôster: "Os Britânicos precisam de você”, 1914, Alfred Leete. Fonte: HOLLIS, 2000, p.29.

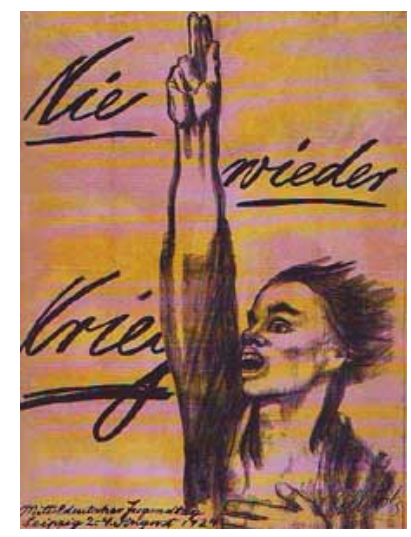

Figura 5 - Pôster: “Chega de Guerra”, 1923, Käthe

Kollwitz. Fonte: HOLLIS, 2000, p.109.

Na declaração de guerra de 1939, o Design Gráfico começava a desempenhar relevante papel na publicidade política dos países. Na Europa, os inimigos eram diminuídos por meio de imagens malévolas e heróicas de membros do partido identificados por símbolos, uniformes e saudações. Estes "representavam a força e a integração de uma crença [...]; nas guerras civis [...] as bandeiras nacionais e os símbolos heráldicos foram substituídos pelo machado [...] pela foice e pelo martelo, pela bandeira vermelha e a suástica" (HOLLIS, 2000, p.109).

No período da $2^{\circ}$ Guerra Mundial, os Estados Unidos, entre 1939 e 1945 estavam passando também pelo fim da Grande Depressão. Houve, nesta época, um aumento da demanda de postos de trabalho. Como a maioria da população masculina estava envolvida na Guerra, ocorreu uma campanha governamental em prol do patriotismo, utilizando cartazes de incentivo à participação das mulheres na produção industrial do país. Deste modo, a ocupação dos postos de trabalho por mulheres aumentou de 10 para $30 \%$.

Foram utilizadas imagens de mulheres fortes e independentes. Isto impulsionou o feminismo em que o ícone principal foi a operária Rosie the Riveter (figura 6). Mais uma vez, como assinala na hermenêutica a utilização de personalidades forte nas campanhas de persuasão são formas simbólicas que fazem parte do imaginário e dos anseios do grupo social a ser alcançado. São formas, composições visuais cujas mensagens plásticas e simbólicas estão repletas de informação. Detalhes como elementos básicos do alfabetismo visual, tais como formas humanas em posturas imponentes e vencedoras, cores institucionais que fazem menção ao país, imagens centralizadas e assertivas. 


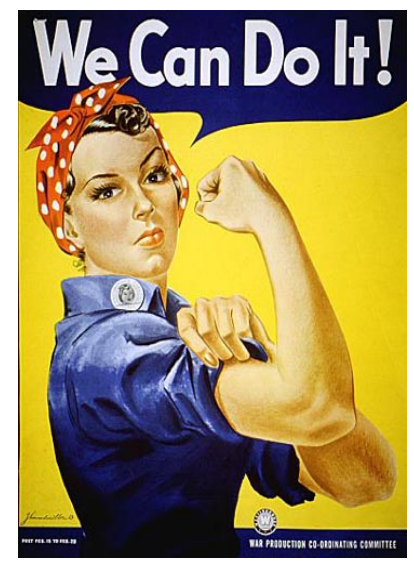

Figura 6 - Poster: “We can do it - Rosi the Reviter”. Design: J. Howard Miller. Fonte: disponível em:

<http://www.rosietheriveterphotos.com/>. Acesso em: 12 fev 2011.

Segundo Heller (2007), pode-se considerar a suástica (figura 7) um dos símbolos mais impactantes sobre a humanidade, como também, o mais antigo no mundo civilizado. Há estudos que argumentam ligação do símbolo ao Ankh, ou Cruz ansata, que se baseia em símbolo do Egito antigo, denominado "chave da vida", sendo essa uma marca de tantas e distantes culturas. Entretanto, a suástica faz parte de uma memória recente, e nenhum outro símbolo provoca tanto medo e ódio e, ao mesmo tempo, tanta relevância e respeito quanto ela. Também foi denominada roda do sol que significa "bem-estar", "boa fortuna" e "sorte", e possui semelhanças com a mística figura svastikaya, um "signo de benção". Essa foi adotada e remodelada por Adolf Hitler no verão 1920 como símbolo dos nazistas, tornando-se o símbolo de associação aos mais terríveis crimes perpetrados pelo homem. É possível se dizer que a suástica ainda continua sendo empregada nos rituais de determinadas culturas ocidentais e orientais.

A suástica historicamente antes da década de 1920 possuía o simbolismo intrincado, porém, sempre benigno, foi até mesmo encontrada em uma escavação de uma tumba pré-histórica no atual estado de Ohio nos Estados Unidos. Durante o século XIX, algumas tribos nativas dos EUA bordavam a suástica em cobertores, em trajes cerimoniais e em objetos de cerâmica. Também, foi aplicada em ornamento arquitetônico e como adorno ou borda de livros, em virtude de ser um símbolo com ligação a boa sorte. Fato interessante é que Hitler foi aspirante a arquiteto e pintor, como também, diletante das artes comerciais e diretor de arte. 0 mesmo defendia que "a ausência de símbolos" poderia tanto acarretar problemas no presente, tais como a falta de união dos membros do partido, quanto era impensável para o futuro, em que seria intolerável não possuir um emblema que simbolizasse o movimento e, assim, pudesse opor-se aos signos comunistas. Hitler realizou até uma análise das cores da suástica, em que o branco seria uma cor que não arrebatava as pessoas, sendo ideal para se associar às virgens castas, porém, não funcionou, pois era um movimento esmagador de uma época revolucionária. Já quanto ao preto, pensou-se que o mesmo não seria suficientemente eletrizante, então, resolveu-se empregar o preto, branco e vermelho, que contemplaria uma composição de cores com a maior resplandecência harmônica existente. A suástica não teria sido adotada se não fosse a vontade de Hitler, assim como também não teria essa eficiência em sua aplicação. É possível dizer que o sistema de identidade de Hitler foi o mais engenhoso programa gráfico já desenvolvido.

Reich (1998, p.97) faz uma aproximação da suástica com o ato sexual e da relação do indivíduo com 
o trabalho, sendo possível perceber em uma representação esquemática da imagem, duas figuras enlaçadas, atribuindo-se então, que "a suástica é, portanto, originalmente um símbolo sexual", o autor ainda acrescenta que "trabalho e sexualidade eram, originalmente, a mesma coisa".

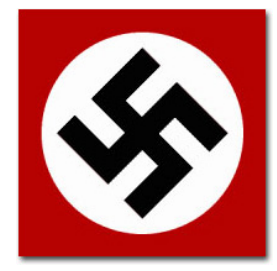

Figura 7 - Suástica. Fonte: <http://proculturaalternativa.blogspot.com/2008/11/o-pior-da-propaganda-ideolgica-o.html> Acesso em: 23 fev 2011.

O símbolo da paz (figura 8 - um tridente de cabeça para baixo e encaixado dentro de um círculo) foi possivelmente o emblema mais marcante ou polarizador durante a década de 60, sendo uma representação da ansiedade e raiva da época, marcada pela Guerra do Vietnã. Surgiu com testes da bomba-H em meados da década de 50, sendo redesenhado em 1954, pelo obscuro designer têxtil inglês Gerald Holtom, para ser empregado na Campanha pelo Desenvolvimento Nuclear (CND). Entretanto, em 1962, o símbolo apareceu em um filme de ficção científica nos Estados Unidos que trazia alertas sobre tragédias em testes nucleares. Há suspeitas de que o símbolo combine as letras $\mathrm{N}$ e D, porém sua forma básica também possui derivações do antigo símbolo rúnico, como também a indícios de interação entre um círculo branco e um quadrado preto. Assim, posteriormente, surgiram variadas versões de cruzes cristãs desenhadas dentro da esfera branca. Durante o final da década de 50, Russel, o atual presidente do CND, e ex-membro de uma associação de socialistas ingleses presenciou várias manifestações em favor do desarmamento e protestos contra o envolvimento inglês. Isso provocou o jornal direitista American Opinion a associar o símbolo a fatores negativos, tais como, o anticristianismo, assim, o logotipo começou a aparecer tanto de cabeça para cima que significava o "homem", como de cabeça para baixo que representava o homem caído (HELLER, 2007).

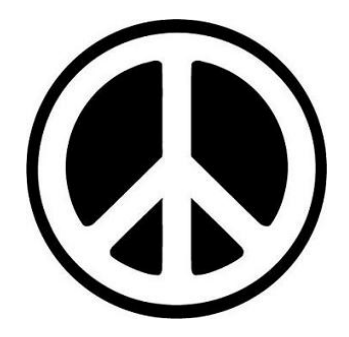

Figura 8 - Símbolo da Paz. Fonte: <baixarvetorgratis.blogspot.com/2010/02/vetor-do-simbolo-dapaz.html> Acesso em: 23 fev 2011.

\section{CONSIDERAÇÕES FINAIS}

Diante de tantas funções atribuídas ao Design Gráfico, a da persuasão é uma das mais intrigantes por utilizar as formas simbólicas para a influência de grupos sociais, favorecendo alguma ideia.

Deste modo, buscou-se estudar o Design Gráfico para a persuasão a partir da hermenêutica de 
profundidade. A delimitação pautou-se na contextualização histórica e cultural, para fundamentar a interpretação das peças gráficas aqui exemplificadas muito utilizadas em campanhas de guerra. Para tanto, estudou-se as funções do Design Gráfico, a Hermenêutica, os aspectos de transmissão cultural e o Design Gráfico para a persuasão.

A hermenêutica de profundidade propõe um conjunto de métodos de análise que possibilitam a interpretação de ideias e, no caso, do Design Gráfico de imagens com linguagem verbal e não verbal. Ao considerar a imagem como texto visual, verificou-se que a hermenêutica se ocupa da tríplice relação de um proferimento que serve como, fundamentado por Habermas (2003: 40-41), a expressão da intenção de um falante; a expressão para o estabelecimento de uma relação interpessoal entre falante e ouvinte; a expressão sobre algo no mundo. Tratou-se neste artigo de um emissor, o designer e de um receptor da mensagem, aquele que irá "consumir" a informação da mensagem.

As formas simbólicas são construções humanas e fazem parte de um fenômeno social e histórico. Estão inseridas na cultura material e imaterial de sociedades e quando impressas em artefatos como pôsteres e panfletos utilizados em situações de conflito são consideradas como artifícios poderosos na obtenção de determinado objetivo político.

Ressalta-se Hollis (2001) quando afirma que o Design Gráfico é uma linguagem imprecisa em contínua expansão. Desta forma, necessita de diferentes métodos de análise, mas que, principalmente, como é apontado por Thompson (1995), não subtraia o contexto histórico e social do objeto analisado. Acredita-se que tal abordagem fundamenta e sustenta uma análise, possibilitando uma interpretação eficaz.

\section{REFERÊNCIAS BIBLIOGRÁFICAS}

AUMONT, J. The Image. Trad. C. Pajackowska, London: PBI Publishing.

BARNARD, M. Graphic design as communication. New York - NY. Routledge, 2005.

CONSELHO FEDERAL DE PSICOLOGIA. Mídia e psicologia: produção de subjetividade e coletividade. 2.ed. / Conselho Federal de Psicologia. Brasília: Conselho Federal de Psicologia, 2009.

FERREIRA, M. Mídia e produções de subjetividade: o poder da mídia. In: Conselho Federal de Psicologia Mídia e psicologia: produção de subjetividade e coletividade. 2.Ed. Brasília: Conselho Federal de Psicologia, 2009.

FRASCARA, J. Diseño gráfico para la gente. Comunicaciones de masa y cambio social. Buenos Aires: Infinito, 2004.

HELLER, S. Linguagens do Design: compreendendo o Design Gráfico. Trad. Juliana Saad, SP: Ed. Rosari. Coleção Fundamentos do Design, 2007.

HOLLIS, R. Design Gráfico: uma história concisa. São Paulo: MartinsFontes, 2001.

OLIVEIRA, S. R. Imagem também se lê. São Paulo: Rosari, 2005.

REICH, W. Psicologia de Massas do Fascismo. São Paulo, Martins Fontes, 1988.

REMOR, L. de C. Auditoria de conhecimento em saúde. Florianópolis: UFSC, 2009.

THOMPSON, J.B. Ideologia e Cultura Moderna: teoria crítica na era dos meios de comunicação de massa. 7 ed. Petrópolis, Rio de Janeiro: Vozes, 1995. 